\title{
Myöhemmän iän opiskelun oikeutus
}

\begin{abstract}
$y$
Myöhemmän iän opiskelun oikeutuksessa on kyse monin tavoin samoista tarpeista kuin yleisemmin ihmiselämässä. Opiskelua perustellaan sekä omana ilona että ulkoapäin vyöryvänä pakkona.
\end{abstract}

ELINIKÄINEN OPPIMINEN on yhteiskuntamme suuri kulttuurinen koulutuskertomus, jonka kantavana ajatuksena on pyrkimys tarjota oppimismahdollisuuksia kaikille koko eliniän ajan. Vaikka elinikäisen oppimisen kertomuksessa korostuvat muodollisen koulujärjestelmän ulkopuolinen koulutus ja myöhemmällä iällä tapahtuvan koulutuksen arvo, ikäsidonnaiset odotukset tarjoavat normatiivisen mallin, jonka mukaan koulut käydään nuorena (Siivonen 2010). Vallitsevissa elinikäisen oppimisen keskusteluissa ymmärrys opiskelusta kietoutuu ammatissa pätevöitymiseen ja painopiste on sen mukaisesti ollut talouskasvua opiskeluillaan tukevassa työikäisessä aikuisväestössä (Glendenning 2001; Muhonen \& Piesanen 2006).

Kun tarkastellaan eläkeikäisten oikeutusta opiskeluun, perustelut törmäävät työelämälähtöisen elinikäisen oppimisen ohella ikääntyvän yhteiskunnan huolidiskurssiin: kerrontaan siitä, kuinka suurten ikäluokkien eläköityessä ja väestön harmaantuessa työllisyysaste heikkenee ja huoltosuhde rapautuu. Suurten ikäluokkien eläköitymisen myötä 65-79-vuotiaiden "nuorten vanhojen" määrän on ennustettu nousevan kuudesta sadastatuhannesta noin miljoonaan. Huolipuheen taustalta löytyy myös muita 2000-luvun suomalaista yhteiskuntaa kuvaavia demografisia piirteitä, kuten ihmisten eliniän piteneminen ja syntyvyyden alhaisuus. (Ojala 2010, 14-18; Jyrkämä 2013.)

Yleisen eliniän nousun seurauksena eläkkeelle siirtymisen ja kuoleman välinen ajanjakso on pidentynyt. Esimerkiksi suomalaiset jäävät eläkkeelle nykyisin keskimäärin hieman yli 60-vuotiaina, mutta elävät sen jälkeen vielä pitkään: naiset noin 25 vuotta, miehet noin 20 vuotta. Eläköityminen ei merkitsekään nyky-yhteiskunnassa vanhuuden alkamista samaan tapaan kuin aiemmin. Puhutaan kolmannesta iästä, toisin sanoen ajasta, jolloin ihminen on vapaa tekemään sen, mitä on aina halunnut tehdä. (Jyrkämä 2013; ks. myös Jyrkämä 2001; Karisto 2002.) Tämän artikkelin tutkimuskohteena oleville "nuorille vanhoille" halu opiskella on yksi elämän tärkeistä asioista, joita eläkkeellä päästään toteuttamaan. 
Tutkin artikkelissa, millaisilla perusteilla työelämän jälkeistä opiskelua oikeutetaan. Elinikäiseen oppimiseen sisältyvän, koko elämän kestävän opiskeluoption kannalta on kiinnostavaa, kuinka työelämän näkökulmasta tuottamatonta myöhemmän iän opiskelua perustellaan ikääntyvässä, kasvavien kustannusten yhteiskunnassamme. Tulkintakehyksenä aineistolle on opiskelun oikeutukseen kiinnittyvät ideologisesti ja poliittisesti latautuvat keskustelut elinikäisestä oppimisesta. Vallitseviin elinikäisen oppimisen keskusteluihin sisältyvillä - oppimiseen, opiskeluun ja koulutukseen suhtautumista muokkaavilla kulttuurisilla jäsennyksillä (Alasuutari 1999, 114-124) - on vaikutuksia siihen, mitä myöhemmän iän opiskelijat voivat tavoitella ja millaisia pakkoja tahtomisiin ja tavoitteisiin sisältyy (vrt. Ojala 2010, 84). Ikääntyvässä yhteiskunnassa opiskeluun, niin kuin aktiivisuuteen ja osallistumiseen ylipäätään, latautuu monenlaisia odotuksia. Kysymys opiskelun oikeutuksesta aktivoituu, kun tarkastelun kohteeksi valitaan elinikäisen oppimisen ideologian normiopiskelijoista, työelämässä olevista tai sinne tähtäävistä poikkeavat, myöhemmällä iällä opiskelevat.

\section{ELINIKÄINEN OPPIMINEN JA RINNAKKAISKÄSITTEET}

Laajimmillaan elinikäistä oppimista on märitelty läpi elämän kestävänä ja eri konteksteissa (formaali, non-formaali, informaali) tapahtuvina prosesseina (Tuomisto 1994a). Kun elinikäistä oppimista tarkastellaan näin laajana, vauvasta vaariin oppimisen käsittävänä ilmiönä, esiin nousee huoli aikuiskoulutuksen erikoisteemojen hukkumisesta koko elämänkaaren kattavan oppimisen suohon (Manninen 2010). Yhtenä osoituksena tarpeesta rajata keskustelua voidaan pitää rinnakkaiskäsitteiden syntymistä. Tämän artikkelin ytimessä on elinikäisen oppimisen käsitehistorian sijaan myöhemmän iän opiskelun perustelut, minkä vuoksi kuvaan tässä elinikäisen oppimisen rinnakkaiskäsitteiden taustahistoriaa vain lyhyesti (ks. lisää Tuomisto 1994b; 2003; Rubenson 2006).

Rubenson (2006) on jäsentänyt elinikäisen oppimisen kansainvälisten keskustelujen historiaa erottamalla kolme eri aikakautta (vrt. Tuomisto 2002; Kauppila 2006). Ensimmäinen kausi (1960-luvulta 1990-luvulle) rakentui demokratian ja humanismin periaatteille ja kiinnittyi UNESCOn maailmanlaajuisesti levinneeseen elinikäisen oppimisen muistioon. Pinnalla olivat kysymykset oikeudenmukaisuudesta ja yhteiskunnallisesta tasa-arvosta. Suomessa samoja keskusteluja käytiin elinikäisen kasvatuksen käsitteen alla, ja ensimmäinen elinikäistä kasvatusta käsittelevä kirja ilmestyi vuonna 1969 (Harva \& Laurila 1969; Alanen \& Sihvonen 1981). Ajalle tyypillinen koulutussuunnittelu oli hyvin koulukeskeistä. Pyrkimys tasoittaa yhteiskunnallisia eroja koulutuspolitiikalla konkretisoitui 1960-70-luvun Suomessa niin peruskoulun rakentamisessa kuin yliopistokoulutuksen vähittäisessä laajenemisessa. (Tuomisto 2002; Kauppila 2006.) Myöhemmin tätä keskusteluperinnettä on nimetty elinikäisen oppimisen sivistysdiskurssiksi (Ojala 2010).

Rubenson (2006) kiinnittää elinikäisen oppimisen toisen aikakauden synnyn myöhäiselle 1980-luvulle, OECDn toimintaan ja kuvaa vaihetta elinikäisen oppimisen liittona talouden kanssa. Keskeinen tekijä elinikäisen oppimisen paluussa politiikkaan oli tarve parantaa kansalaisten työllistettävyyttä korkean rakennetyöttömyyden aikana, joka koetteli erityisesti heikoimmin koulutettuja (Euroopan komissio 2000, 9). Elinikäistä oppimista perusteltiin tyypillisesti kansakunnan kilpailukyvyllä, ja poliittiset toimijat ottivat markkinalähtöisen elinikäisen oppimisen version omakseen pian, toisin kuin aikuiskoulutuksen kentän toimijat. Tämän työelämää varten oppimista korostavan elinikäisen oppimisen asema vahvistui Suomessa koulutuspoliittisissa keskusteluissa komiteamietinnön, Oppimisen ilo: kansallisen elinikäisen oppimisen strategia valmistuttua vuonna 1997 (OPM 1997). Komiteamietintö sai osakseen paljon kritiikkiä. Alkuperäisen elinikäisen kasvatuksen käsitteen humanististen arvojen kritisoitiin hukkuneen talouselämäkeskeisen elinikäisen oppimisen alle (esim. Silvennoinen, Tulkki \& Honkonen 1998; Tuomisto 2003).

Siirtymistä elinikäisen kasvatuksen keskusteluista elinikäisen oppimisen markkinakeskeiseen versioon on luonnehdittu sekä näkökulman laajenemisella kaikkeen oppimiseen - ei ainoastaan koulutuksessa tapahtuvaan - että oppimisvastuun siirtymisellä 
yhteiskunnalta yksilölle (Raggat, Edwards \& Small 1996, 2; Tuomisto 2002, 20; Moore 2003, 28 ). Suomalaisissa keskusteluissa esillä on ollut myös elinkautisen oppimisen käsite, jonka alla ilmiöön on otettu edellistä jyrkempi kanta kärjistämällä yksilön vastuu jatkuvasta oppimisesta elinkautiseksi pakoksi. Elinkautinen oppiminen on ollut tyypillisimmin esillä elinikäistä oppimista polemisoivissa teksteissä (pääkirjoitukset, mielipidekirjoitukset), ei niinkään tutkimuskirjallisuudessa.

Työelämänikäiseksikin oppimiseksi (Ojala 2010) nimitetty elinikäisen oppimisen markkinalähtöinen versio elää edelleen elinikäisen oppimisen keskusteluissa, mutta sen rinnalle on syntynyt vuosituhannen vaihteessa pehmeämpi elinikäisen oppimisen versio, jonka Rubenson (2006) erottaa elinikäisen oppimisen historian kolmantena aikakautena. Hän luonnehtii kyseistä vaihetta vertaamalla sitä giddensiläiseen äärilaitoja yhdistävään kolmannen tien (Third Way) ajatteluun. Elinikäisen oppimisen kolmas vaihe pyrkii ylittämään aikaisempien keskustelujen siltoja yhdistämällä keskustelujen taustalla vaikuttavia yhteiskunnallisia, kulttuurisia ja taloudellisia tavoitteita. Elinikäisen oppimisen näkökulmasta olennaiseksi nousee ajatus tietotalouden kehittymisen voimaannuttavasta vaikutuksesta ja ihmisten mahdollisuudesta muokata elämänkulkujaan, uraansa, terveyttään, koulutustaan ja turvallisuuttaan tiedon avulla. (Rubenson 2006; vrt. Delanty 2003; Euroopan komissio 2000, 9-10.)

Suomessa eroa elinikäisen oppimisen toisen vaiheen talouskeskeisiin keskusteluihin on tehty elämänlaajuisen oppimisen käsitteellä (Sallila 2003; Muhonen $\&$ Piesanen 2006). Samaan tapaan opiskelun roolia ihmisten elämässä kuvataan myös keskusteluissa myöhäismodernista, jossa opiskelu nähdään ammattiin pätevöitymistä laajempana ja siitä puhutaan itsensä toteuttamisena ja identiteetin rakentamisena (Tikka 1990; ks. myös Silvennoinen 2007). Opiskelun merkitys elämänkulussa ei siten kiinnity pelkästään tiettyyn elämänvaiheeseen, vaan koskee kaikenikäisiä.

\section{TUTKIMUKSEN LÄHTÖKOHDAT}

Tutkimuskohteenani on opiskelu, ei oppiminen, ja käytän eläkeikäisten opiskelusta käsitettä myöhem- män iän opiskelu (vrt. Ojala 2010). Myöhemmän iän opiskelun oikeutuksesta keskusteltaessa ideologisesti ja poliittisesti latautuneet kulttuuriset jäsennykset ja näkökulmaerot tiivistyvät elinikäisen oppimisen käsitteiden kirjossa. Tarkastelen artikkelissa myöhemmän iän opiskelun oikeutusta ja perustelujen suhdetta erilaisin arvoin latautuneisiin elinikäisen oppimisen käsitteisiin. Käsitteet eivät ole tasavahvasti edustettuina nykyisissä elinikäisen oppimisen keskusteluissa, mutta erilaisista painotuksista riippumatta ne luovat kehykset mahdollisille myöhemmän iän opiskelun perustelujen repertuaarille.

Artikkeli on osa väitöstutkimustani, jossa tutkin ikääntyvien yliopistotoimintaa ja sotien sukupolven yliopistollisuudelle antamia merkityksiä opiskelijoiden aikaisempien opinteiden valossa (Muhonen \& Ojala 2004; Muhonen \& Piesanen 2006; Muhonen 2011; Muhonen 2013). Tämän artikkelin aineisto koostuu Jyväskylän Ikääntyvien yliopiston toimintakertomuksista. Työelämän jälkeistä opiskelutoimintaa on muuallakin, mutta ikääntyvien yliopistoissa myöhemmän iän opiskelu erottuu omaleimaisena kokonaisuutena. Varsinaisissa yliopistoissa myöhemmän iän opiskelu rakentuu yksittäisten vanhempien ihmisten opiskelusta, yksittäisissä aineissa opiskellen (Muhonen \& Piesanen 2006).

Ikääntyvien yliopistotoiminta alkoi Suomessa keväällä 1985, kun ensimmäinen ikääntyvien yliopisto perustettiin Jyväskylään. Valitsin Jyväskylän Ikääntyvien yliopiston toimintakertomukset tutkimusaineistoksi, koska se on valtakunnallisesti merkittävä toimija. Opiskelijamääriltään Jyväskylän jälkeen seuraaviksi suurimmissa ikääntyvien yliopistoissa, Tampereella ja Helsingissä, ei ole tehty toimintakertomuksia.

Jyväskylän Ikääntyvien yliopiston opiskelijoiden syntymävuosista ei ole saatavilla tilastotietoa, mutta opiskelijoiden on arvioitu olevan pääosin noin 65-vuotiaita eläkeläisiä. Vaikka toimintaan osallistuu niin kansakoulun kuin korkeakoulututkinnon suorittaneita, ovat opiskelijat taustoiltaan koulutetumpia kuin ikäisensä perusväestö. Vuoden 2012 kevätlukukaudella kansa-, keski- ja peruskoulun käyneitä oli opiskelijoista noin 30 prosenttia, samoin korkeakoulututkinnon suorittaneita. Toisen asteen tutkinto oli 40 prosentilla opiskelijoista. Opiskelijarekisterissä 
oli kirjoilla 2305 henkilöä, joista valtaosa oli naisia. (Rossi 2012.)

Toimintakertomukset ovat vuosilta 1987-1999 ja 2002-2008 ( $n=18)$. Resurssien puute on aiheuttanut niiden laadintaan katkoksen kolmena lukuvuonna (1999-2002). Vuoden 2008 rehtorin vaihdoksen jälkeen Jyväskylän Ikääntyvien yliopistossa ei ole enää tehty toimintakertomuksia. Toimintakertomuksiin kirjoittavat pitkälti vuodesta toiseen samat henkilöt. Heistä suurin osa osallistuu luentojen lisäksi seminaaritoimintaan eli on niin sanottuja sisäpiiriläisiä (Muhonen \& Ojala 2004; Ojala 2010). Toimintakertomuksissa kirjoittajien syntymävuosia ei ole ilmoitettu. Sen sijaan sukupuoli on näkyvillä osassa teksteissä, mutta esimerkiksi nimettömissä luentopalautteissa kirjoittajan sukupuoli ei näy. Tässä artikkelissa olen kiinnostunut yleisesti myöhemmän iän opiskelun oikeutuksesta, en käytettyjen perustelujen kiinnittymisestä sukupuoleen.

Analysoin toimintakertomusten osia, joissa opiskelijat kirjoittavat kokemuksistaan luennoille, seminaareihin ja tutortoimintaan osallistumisesta. Nämä osat koostuvat tyypillisesti kurssipalautteista, minkä lisäksi mukana on tekstejä, jotka on kirjoitettu varta vasten toimintakertomuksiin. Kesäyliopiston rehtori ja suunnittelija ovat toimittaneet toimintakertomukset. Tässä suhteessa aineisto ei edusta puhtaasti tai pelkästään opiskelijoiden ääntä. Verrattuna väitöstutkimukseni toiseen, elämäkerralliseen aineistoon, toimintakertomuksissa kirjoitetaan asiapitoisesti ja ytimekkäästi. Sen sijaan opinteitä muistellessaan opiskelijat kirjoittavat enemmän itselleen konstruoiden opiskelijuuttaan ensimmäisistä koulupäivistä ikääntyvien yliopistoon saakka pyrkimyksenään selvittää lukijalle (ja itselleen) henkilökohtaisen opiskeluhistorian kautta, miksi juuri minä opiskelen vielä eläkeiässä. Päinvastaisesti toimintakertomuksissa kirjoittaminen on julkista ja niiden rooli voidaan nähdä organisaation oikeutuksen legitimoijina sekä imagon rakentamisena. Ikääntyvien yliopiston toimintakertomuksissa luodaan positiivista imagoa myöhemmän iän opiskelusta ja omasta instituutiosta. Ikäviä asioita, kuten elämäkerrallisessa tutkimusaineistossa ilmeneviä opiskelijakollegojen pätemisiä tai latistuneita odotuksia suhteessa toiminnan yliopistolliseen tasoon ei mainita. Toimintakertomukset toimivat yhteisöllisyyden vahvistajina luodessaan yhteistä kieltä, jaettuja näkemyksiä ja pelisääntöjä ja niiden avulla pyritään saamaan mukaan uusia ihmisiä.

Edellisten vuosien toimintakertomukset näyttävät luovan kehyksen seuraaville, sillä toiminnan perustelujen kirjo ei muutu tarkastelemieni vuosien 1987 2008 välillä. Sen sijaan toimintakertomusten sisältöjen tyylillinen painopiste muuttuu. Kun opiskelijat kirjoittavat uusimmissa toimintakertomuksissa, tyyli on tapahtumista ja opiskelluista asioista raportoiva. Vanhemmissa toimintakertomuksissa opiskelijoiden oma ääni tulee enemmän esille vapaampana kerrontana toiminnan anneista, minkä vuoksi enemmistö aineistolainauksista on otettu 1980- ja 1990-luvuilla kirjoitetuista toimintakertomuksista.

Metodologinen lähestymistapani täsmentyy sosiaaliseksi konstruktionismiksi kuvattuun ajattelutapaan, joka painottaa kieltä käytäntönä. Sen lisäksi, että kielellä kuvataan maailmaa, sen ajatellaan merkityksellistävän, järjestävän ja uusintavan sitä sosiaalista todellisuutta, jossa elämme (esim. Berger \& Luckmann 1999). Esimerkiksi yleisesti vallalla olevat, opiskeluun liittyvät kulttuuriset jäsennykset vaikuttavat toimintaamme kehystämällä, muokkaamalla ja luomalla opiskelumahdollisuuksien odotushorisontteja. Maltilliseksi konstruktionismiksi lähestymistapani tekee se, että en ole kiinnostunut kielestä irrallisena kontekstista, jossa se tuotetaan. Artikkelin tutkimusasetelmassa maltillinen konstruktionismi on kirjoitettu sisään näkemyksessä siitä, kuinka elinikäisen oppimisen keskustelut luovat ikään kuin kehyksen mahdollisille myöhemmän iän opiskelun perustelujen repertuaareille. Elinikäisen oppimisen ohella aineisto kiinnittyy toimintakertomusten yleiseen genreen, koulutusta arvostavaan ikääntyvien yliopistoyhteisöön sekä laajemmin teemaa sivuaviin aikalaiskeskusteluihin, kuten ikääntyvän yhteiskunnan ja kolmannen iän keskusteluihin.

Aineiston analyysimetodina on laadullinen sisällönanalyysi. Olen lukenut toimintakertomuksia kiinnittämällä huomiota kohtiin, joissa opiskelijat kirjoittavat oman opiskelunsa motiiveista tai perustelevat laajemmin yhteiskunnallisessa kontekstissa myöhemmän iän opiskelua ja ikääntyvien yliopis- 
totoimintaa. (vrt. Patton 2002, 431-462; Creswell 2007, 147-176.) Aloitin aineiston analyysin operationalisoimalla tutkimuskysymyksen myöhemmän iän opiskelun oikeutuksesta seuraavanlaisiksi kysymyksiksi: Miksi kirjoittajat opiskelevat eläkeikäisenä ja miksi juuri ikääntyvien yliopistossa? Mitä toiminta heille antaa? Miten ikääntyvien yliopistotoimintaa ja myöhemmän iän opiskelua ylipäätään perustellaan? Teemoittelin myöhemmän iän opiskelun ja ikääntyvien yliopistotoiminnan oikeutusta kuvaavat perustelut seuraaviin luokkiin: opiskeluhaaveiden täyttyminen, vertaisyhteisön arvo oppimisympäristönä, tietoteknologiataidot, vaikutusmahdollisuudet, sosiaaliset suhteet ja yhteisöllisyys, arjen rytmi, fyysinen terveys, henkinen terveys, yhteiskunnalliset säästöt, henkinen kasvu, uuden oppiminen sekä ajassa mukana pysyminen. Artikkeli etenee esittelemällä kyseisiin teemoihin ja elinikäisen oppimisen eri käsitteisiin kietoutuvien keskustelujen analyysiin perustuvat viisi myöhemmän iän kulttuurista jäsennystä. Artikkelin lopussa esitän analyysin tuloksena elinikäisen oppimisen ja myöhemmän iän kulttuuristen jäsennysten nelikentän (taulukko 1).

\section{KUINKA MYÖHEMMÄN IÄN OPISKELUA PERUSTELLAAN?}

\section{Toinen mahdollisuus sukupolvikysymyksenä}

"Yliopisto minun maailmassani merkitsee jotain ylempää, jalompaa ja ehkä pyhempääkin hengen viljelyä. Ehkä siksikin, kun yliopiston vaikutus on elämässäni ollut melkein tavoittamattomissa (...) kun sitten edellä mainittuihin kuvioihin liittyen sain [Jyväskylän ikääntyvien yliopiston sivutoimipisteessä] liittyä Ikääntyvien yliopistonopiskelijaksi, niin olihan se taivaan lahja." (lukuvuoden 19951996 toimintakertomus)

1900-luvun alkupuolella syntyneiden ikääntyvien yliopiston opiskelijoiden elämässä yliopisto-opiskelu on ollut harvinaista. Juha Kauppila (1996; 2002) on nimennyt ennen vuotta 1935 syntyneiden ikäluokan sodan ja niukan koulutuksen sukupolveksi. Sukupolven kulkemalla opintiellä koulutusvaihtoehdot ovat olleet vähäisiä ja opiskelu yliopistossa on monelle pit- käaikaisten unelmien täyttymys (Muhonen \& Ojala 2004; Muhonen 2011; Muhonen 2013).

Ikääntyvien yliopisto esitetään toimintakertomuksissa instituutiona, joka konkretisoi elinikäisen kasvatuksen ideologiaan sisältyvän lupauksen tasa-arvoisista opiskelumahdollisuuksista tarjoamalla "toisen mahdollisuuden” kaikenikäisille. Aikuiskoulutuksen kentällä toisilla mahdollisuuksilla viitataan opiskelun luomiin mahdollisuuksiin paikata nuoruuden koulutuksen puutteita sekä tyydyttää toteutumattomia koulutushaaveita (esim. Kilpeläinen 2000). Päinvastoin kuin työikäisillä, myöhemmän iän opiskelussa kyseinen ilmiö ei kiinnity ammatinvaihtoon tai uralla etenemiseen vaan sotien sukupolven kokemaan koulutuksen puutteeseen.

"Monesti olen ollut tyytyväinen, että vihdoinkin saan opiskella yliopistossa ja seminaarissa." (1995-1996)

Opiskelijoille tasa-arvoiset opiskelumahdollisuudet tarkoittavat mahdollisuutta opiskella itsensä ikäisten kanssa, esimerkiksi käsiteltävien aiheiden koetaan liittyvän omaan elämänvaiheeseen ja opiskelussa voidaan edetä itselle sopivaan tahtiin. Osa on kokenut aiemmissa opinnoissaan opiskelun nuorten kanssa haastavaksi.

"Vieraiden kielten opiskelu nuorten kanssa on nöyryyttävää. He nauravat ääntämistä ja kyllästyvät, kun vastaus tulee hitaammin kuin nuoremmilla. Kerran opettaja sanoi minulle: Meidän on päästävä eteenpäin, vastausvuoro seuraavalle. Kuuntele sinä nuorempia." (1996-1997)

Ikääntyvien yliopistossa opiskelua arvostetaan myös opiskelijalähtöisyyden vuoksi: tarjottavien opintojen sisältöön voidaan itse vaikuttaa, eikä tarvitse edetä suorituspainotteisesti. Vertailua tehdään suhteessa varsinaisiin yliopistoihin. Samanhenkisessä porukassa koetaan uskallettavan kysellä vapaammin epäselviä asioita ja kynnys osallistumiseen madaltuu.

"Täällä on ollut siitä mukava käydä, kun kaikki ovat jo "varttunutta" väkeä - eikä ilmeisesti varsinaisena tietokoneaikana kasvaneita." (1994-1995) 


\section{Yhteiskunnallinen ja sosiaalinen osallisuus}

Elinikäisen kasvatuksen ideologiaan sisältyvät humanistiset ihanteet oikeudenmukaisuudesta, yhdenvertaisuudesta ja sivistyksestä kiinnittyvät myöhemmän iän opiskelun yhteydessä kysymykseen yhteiskunnallisesta osallisuudesta. Yhteiskunnan nähdään olevan velvollinen tarjoamaan koulutusmahdollisuuksia tasa-arvoisesti kaikille. Toimintakertomuksissa yhteiskuntaan kuulumisen tunne kiinnittyy tietotekniseen osaamiseen, vaikutusmahdollisuuksiin, sosiaalisiin suhteisiin ja yhteisöllisyyteen.

Sankari $(2004,105)$ on kuvannut tietotekniikkaa ikääntyneille kätevänä välineenä, jonka hallitseminen luo tunteen siitä, että on ajassa mukana. Vaikka ikääntyvien yliopiston opiskelijat kertovat tietotekniikan välineellisestä arvosta konkreettisten asioiden saavuttamisessa, olennaisemmaksi tietotekniikkataitojen osaamisen merkitykseksi nousee tunne siitä, että on ajassa mukana. Siinä missä oppiminen on toisaalta optio uusiin mahdollisuuksiin, koko elämän kestävästä oppimisesta on esitetty tulleen myös moraalinen velvoite ja eräänlainen kansalaisuuden ja yhteiskuntaan kuulumisen edellytys (Karvonen \& Rahkonen 2002). Pelko siitä, että ei enää pysty jakamaan osallisuutta siihen mistä puhutaan tuo tietotekniikan opiskeluun mukanaan pakon. Pakko ja oppimisen elinkautisuus kulkevat mukana opiskelijoiden perusteluissa suhteessa teknologian kehitykseen: mikäli et opiskele, uhkana on ajasta jälkeen jääminen. Eräs opiskelija kertoo tunnoistaan eläkkeelle jäädessään:

"Päiväkotilapset, koululaiset, nuoret, nörtit ja työikäiset puuhastelivat tietokoneen kimpussa ja puhuivat ihan untta kieltä. Mediassa mainittiin toistuvasti kolme kirjainta www, joiden takaa asiasta kuin asiasta saattoi hankkia lisää tietoa internetistä. Sähköposti tuntui houkuttelevalta ja laskujakin patisteltiin maksamaan omassa peräkammarissa. (... En halunnut pudota kelkasta." (2004-2005)

Tietotekninen osaaminen on yksi osaamisalueista, joilla erot ikäluokkien välillä ovat suuret ja se mielletään tyypillisemmin nuorten kuin ikääntyneiden valtakuntana (Sankari 2004). Tietoteknisen osaamisen mieltäminen nuorempien taitolajina kiinnittyy osittain koulun ja työelämän rooliin kyseisten taitojen päivitys- ja ylläpitopaikkana. Ikääntyvien yliopistossa vanhempien ikäluokkien tarve tietoteknisten taitojen opiskeluun näkyy myös kurssitarjontaan osallistumisessa: atk-kurssit ovat vuodesta toiseen suosituimpia kursseja. Aineiston ensimmäisten vuosien, 1980-90-lukujen toimintakertomukset havainnollistavat teknologian kehitysvauhtia, aikaa jolloin internet ja kännykät eivät olleet vielä arkipäiväistyneet, eikä puhuttu sosiaalisesta mediasta.

"(... ) Uutta tulee koko ajan. Tekniikka on lisääntymässä: televisiot, videot, tietokoneet, satelliitit, pankkiautomaatit. On pakko olla tässä kaikessa mukana ja vielä tekemisissä kaiken kanssa." (1990-1991)

Sen lisäksi, että ikääntyvien yliopistossa opiskelua perustellaan mahdollisuutena opiskella tietoteknologisia taitoja, toiminnan kerrotaan tarjoavan vaikutuskanavia. Ryhmäytymällä opiskelijat vahvistavat vaikutusmahdollisuuksiaan.

"Projektiryhmän tarkoituksena on ottaa kantaa ja tarvittaessa esittää myös kritiikkiä meitä ikääntyviä koskevissa hallinnollisen tason suunnittelussa ja päätöksissä. Tosiasiahan on että me ikääntyvät emme ole mukana missään sosiaalisen verkoston päätöksenteossa eikä meiltä kysytä mitä me haluamme tulevaisuudelta." (1989-1990)

"Kirjoittajaseminaarissa olemme tällä lukukaudella ottaneet kantaa moniin meitä kismittäviin asioihin." (2004-2005)

Opiskelijoissa kansalaistaitojen opiskelu ja erityisesti mahdollisuus päästä hyödyntämään niitä käytännössä on herättänyt innostusta.

"Aina vain uusia mahdollisuuksia avautui, kun samanaikaisesti aloitettiin sekä käytännön englannin kielen, että tietotekniikan opiskelu. Tavoitteena oli kansainvälisten yhteyksien ja opiskelijakontaktien luominen. Hämmästys oli melkoinen, kun huomasimme olevamme ikäpolvemme edelläkävijoitä Euroopan maissa." (2004-2005) 
Yhteiskunnallinen osallisuus on myös sosiaalista osallisuutta, sosiaalisia suhteita ja yhteisöllisyyttä, joiden merkitys korostuu eläkkeelle siirryttäessä. Uudessa elämänvaiheessa tyhjyyttään ammottava kalenteri ja luopuminen työyhteisöstä sekä päivittäisistä työntekoon liittyvistä rutiineista saattavat aiheuttaa epävarmuuden tunteita. Säilyttääkseen yhteiskunnassa kiinnipysymisen tunteen työelämästä poisjäämisen jälkeen, ihmiset etsivät uutta, työnjälkeistä identiteettiä osallistumalla aktiivisesti moninaisiin toimintoihin. (Karisto 2002; Muhonen \& Ojala 2004.) Arjen rytmitys ja sosiaaliset suhteet ovat monelle syy osallistua ikääntyvien yliopistotoimintaan. Osalle ikääntyvien yliopiston opiskelijayhteisö korvaa menetettyä työyhteisöä, toisaalta toiminnan parissa tavataan vanhoja työkavereita.

"Tunsin riemua tästä yhteenkuuluvuudesta." (1992-1993)

\section{Kustannustehokas ikääntyminen}

Elinikäisen oppimisen ideaalille vastakkaisessa, työelämälähtöisessä elinikäisen oppimisen keskustelussa korostuvat teollisuusyhteiskunnalle tyypilliset arvot, kuten kasvu, muutos ja kehitys ja ne kytkeytyvät tyypillisesti talouskasvuun ja tehokkuuteen. Opiskelun nähdään palvelevan ammattiin pätevöitymistä, joten diskurssi ei juuri tarjoa työiän ohittaneille opiskelua oikeuttavaa toiminta- tai odotushorisonttia. Tosin, vaikka opiskelijat ovat työelämän ulkopuolisina näkymättömiä tässä elinikäisen oppimisen diskurssissa, he käyttävät keskustelujen taustalla olevia taloudelliseen kestävyyteen ja kilpailukykyyn yleisemmin liittyviä arvoja.

Opiskelua ikääntyvien yliopistossa perustellaan terveyttä edistävänä toimintana. Näkökulmana terveyteen liittyvissä perusteluissa esitetään tyypillisesti sekä opiskelijan oman terveyden säilyttäminen että tuottavuusargumentti siitä, kuinka opiskelun positiiviset terveysvaikutukset heijastuvat yhteiskuntaan säästyvinä sairauskuluina.

"Mikä sijoitetaan ikääntyvän väestönosan fyysisen ja henkisen kunnon ylläpitoon on poissa sosiaali-ja terveyskuluista." (1991-1992)
"IKYO [Ikääntyvien yliopisto] -annos viikossa pitää lääkärin loitolla.” (1992-1993)

Elinikäisen oppimisen keskusteluihin on luonnehdittu sisältyvän oletus yksilön vastuusta selviytyä muuttuvassa ja alati uusia taitoja vaativassa maailmassa uutta jatkuvasti oppimalla (Raggat, Edwards \& Small 1996,2). Elinikäisen oppimisen yksilöä vastuullistava puhe kääntyy myöhemmän iän opiskelun perusteluissa yksilön vastuuksi taistella vanhuutta ja sairauksia vastaan oppimalla ja opiskelemalla. Kun opiskelijat perustelevat myöhemmän iän opiskelun positiivisia vaikutuksia terveyteensä, mukana perusteluissa kulkee uhka raihnaisesta vanhuudesta, jota vastaan taistellaan osallistumalla ikääntyvien yliopistotoimintaan. Ikääntyvien yliopisto-opiskelija välttää pienet kolotukset keskittämällä ajatuksensa hyödylliseen tekemiseen - tässä tapauksessa opiskeluun.

"Mieleen hiipivä masennus, tuo ikääntyvän ihmisen yleistauti, joka sivuoireinaan tuo kivut ja kolotukset, ei kovin helpolla saa otetta seminaarilaisista." (1988-1989)

"(... ) kun on päänvaivaa, ruumiin vaivat tuntuvat vähäisemmältä." (1990-1991)

\section{Itsensä toteuttaminen}

Elämänlaajuisen oppimisen käsitteen alla kulkevat keskustelut ovat rakentuneet elinikäisen oppimisen työelämäpainotteisiin ja talouskeskeisiin keskusteluihin verrattuna yksilökeskeisestä näkökulmasta. Myös toimintakertomuksissa myöhemmän iän opiskelua perustellaan omia tarpeita ja lähtökohtia pohdiskellen. Perustelut muistuttavat Moodyn itsensä toteuttamisen mallia, jossa on kyse opiskelun avulla saavutettavasta henkisestä kasvusta, itsetiedostamisen syvenemisestä tai viisaasta vanhenemisesta (Moody 1976, 8-11; Tikka 1990, 104-105). Toimintaa kuvataan vertauskuvallisesti kertomalla luentojen merkitsevän "keidasta arjen keskellä" ja opiskelun olevan: "aukko arjen todellisuuteen, henkireikä, hyppäys arkisista asioista kokonaan uusien aiheiden maailmaan".

Vaikka ikääntyvien yliopistossa opitaan konkreettisesti uusia asioita, (kuten atk-taidot, sukututkimus tai englannin kieli) uuden oppimisessa on 
kyse yleisemmin inspiroivasta, abstraktimmasta tarpeesta oivaltaa uutta sekä itsestään että elämästä yleensä. Uusien asioiden opiskelusta haetaan vastapainoa arjen tuttuudelle. Osittain tarve haluun oppia uutta kytkeytyy opiskelijoiden ikään: elämänvarrella monet asiat ovat jo "tympäisevän moneen kertaan koettuja". (1996-1997)

"Keskusteltuani ATK-kurssitoverieni kanssa, tulin siihen tulokseen, että meillä kaikilla on yhtenevä tiedonjano kaikkeen uuteen ja tämä atk-ala jos mikä, on sitä uutta." (1987-1988)

Opiskelu selventää omia ajatuksia ja uutta oppimalla saadaan eväitä oman elämän lisäksi laajemminkin koko ihmiselämän perimmäisten kysymysten ymmärtämiseen. Opiskelijat kirjoittavat omin sanoin itseluottamuksen kohenemisesta ja elämän tarkoituksen löytämisestä. Opiskelun kerrotaan avartavan ajatuksia ja antavan eväitä tulevaisuuteen.

"Seminaari on auttanut minua ymmärtämään vähän paremmin itseäni, ja toivottavasti myös lähimmäisiäni. Se on auttanut minua saamaan vastauksia kysymyksiin: Kuka minä olen? Miten minusta on tullut se, mikä nyt olen? Kuka on kirjoittanut elämäni?" (1989-1990)

\section{MYÖHEMMÄN IÄN OPISKELUN KULTTUURISET JÄSENNYKSET}

Toimintakertomusten analyysi havainnollistaa myöhemmän iän opiskelun ja elinikäisen oppimisen suhteen jännitteisen kentän: opiskelua perustellaan niin yksilön ja arjen kuin yhteiskunnan ja politiikan näkökulmista - omana ilona sekä ulkoapäin vyöryvänä pakkona. Tutkimus nostaa esiin viisi myöhemmän iän opiskelun oikeutusta kuvaavaa kulttuurista jäsennystä: 1) toinen mahdollisuus sukupolvikysymyksenä, 2) yhteiskunnallinen ja sosiaalinen osallisuus, 3) kustannustehokas ikääntyminen 4) itsensä toteuttaminen ja 5) teknologian pakkovalta.

Vaikka opiskelijat ovat työelämän ulkopuolisina elinikäisen oppimisen politiikan marginaalissa, he oikeuttavat opiskeluaan käyttämällä elinikäisen oppimisen keskusteluihin sisältyviä erilaisia arvonäkökulmia, joita kuvaan tässä kahdella ulottuvuudella (taulukko 1). Ideologian tasolla sekä elinikäisen oppimisen että myöhemmän iän opiskelun perustelut jäsentyvät humanismi-homo economicus -ulottuvuudella. Humanistisista arvoista myöhemmän iän opiskelun perusteluissa painottuvat oikeudenmukaisuus ja yhdenvertaisuus suhteessa työikäisen väestön opiskelumahdollisuuksiin. Vastakohtaisesti homo economicus -ulottuvuudella viittaan perusteluihin, joissa

\begin{tabular}{|c|c|c|c|}
\hline \multirow{3}{*}{$\begin{array}{l}\text { Taulukko } 1 . \\
\text { Elinikäinen } \\
\text { oppiminen ja } \\
\text { myöhemmän } \\
\text { iän opiskelun } \\
\text { kulttuuriset } \\
\text { jäsennykset. }\end{array}$} & & Humanismi & Homo economicus \\
\hline & Yhteiskunta & $\begin{array}{l}\text { ELINIKÄINEN KASVATUS } \\
\text { 1. toinen mahdollisuus sukupolvikysymyksenä } \\
\text { - opiskeluhaaveiden täyttyminen } \\
\text { - vertaisyhteisö oppimisympäristönä } \\
\text { 2. yhteiskunnallinen ja sosiaalinen osallisuus } \\
\text { - tietoteknologiataidot } \\
\text { - vaikutusmahdollisuudet } \\
\text { - sosiaaliset suhteet ja yhteisöllisyys } \\
\text { - arjen rytmi }\end{array}$ & $\begin{array}{l}\text { ELINIKÄINEN OPPIMINEN } \\
\text { 3. kustannustehokas ikääntyminen } \\
\text { - fyysisen ja henkisen terveyden } \\
\text { edistäminen } \\
\text { - yhteiskunnalliset säästöt }\end{array}$ \\
\hline & Yksilö & $\begin{array}{l}\text { ELÄMÄNLAAJUINEN OPPIMINEN } \\
\text { 4. itsensä toteuttaminen } \\
\text { - henkinen kasvu } \\
\text { - uuden oppiminen }\end{array}$ & $\begin{array}{l}\text { ELINKAUTINEN OPPIMINEN } \\
\text { 5. teknologian pakkovalta } \\
\text { - ajassa mukana pysyminen }\end{array}$ \\
\hline
\end{tabular}


korostetaan taloudellisen hyödyn maksimointia ja tehokkuusideologiaa. Sen lisäksi, että myöhemmän iän opiskelun perusteluissa korostuvat niin taloudelliset kuin humanistiset arvot, keskusteluja leimaa vastakkainasettelumainen jako suhteessa siihen, perustellaanko opiskelua $y k s i l o ̈ n$ vai $y$ hteiskunnan näkökulmasta. Nelikenttä tiivistää elinikäisen oppimisen keskustelujen ja myöhemmän iän opiskelun oikeutusta kuvaavien kulttuuristen jäsennysten ideologiset jännitteet ja näkökulmaerot.

\section{MYÖHEMMÄN IÄN OPISKELUN MAHDOLLISUUDET JA PAKOT}

Paljon siitä, mitä tutkimuksessa on havainnollistettu konstruoimalla myöhemmän iän opiskelun kulttuurisia jäsennyksiä tiivistyy W.I. Thomasin kuuluisissa neljässä toiveessa. Thomasin mukaan ihmiset toivovat turvallisuutta, elämänhallintaa, haluavat kokea uutta sekä tarvitsevat tunnustusta (Thomas 1923). Myöhemmän iän opiskelun oikeutuksessa on kyse monin tavoin samoista tarpeista, jotka kuvaavat yleisemmin ihmiselämää, eivät pelkästään tietyn ikäisten ihmisten oikeutta opiskeluun. Tutkimuksessa myöhemmän iän opiskelun oikeutusta on kuitenkin peilattu elinikäisen oppimisen keskusteluihin tarkoituksena selvittää, kenellä ja millaisin ehdoin yhteiskunnassamme ajatellaan olevan oikeus opiskella. Elinikäisen oppimisen kaltaiset poliittiset käsitteet ja niihin sisältyvät kulttuuriset ymmärrykset vaikuttavat siihen, millaisia odotushorisontteja ihmisillä on, minkä vuoksi niiden tutkiminen ja auki purkaminen on tärkeää.

Niin elinikäisen oppimisen politiikkaan kuin politiikkoihin ylipäätään sisältyy normatiivisia oletuksia siitä, kuinka meidän tulisi elää. Artikkelissa oikeutta myöhemmän iän opiskeluun on käsitelty ikääntyvien yliopiston toimintakertomuksista ja elinikäisen oppimisen keskusteluista piirtyvää kuvaa vasten. Tällöin opiskelu on ikään kuin implisiittisesti sisäänkirjoitettu sekä aineistoon että tutkimusasetelmaan arvona sinänsä. Sen ohella, että tutkimuksen tuloksina esitetyt myöhemmän iän opiskelun kulttuuriset jäsennykset kuvaavat eläkeikäisten opiskelua oikeuttavia näkökulmia, ne kertovat myös vanhoihin ihmisiin kohdistuvista odotuksista ja paineista. Artikkelin ai- neistona ovat yhden ikääntyvän yliopiston toimintakertomukset. Vaikka toimintakertomukset tekstityyppinä voivat olla hyvinkin sisäänpäin lämpiäviä, tutkimustuloksena esitettyjen myöhemmän iän kulttuuristen jäsennysten yleistettävyyttä voidaan perustella tulosten kiinnittymisellä paikallisten tekijöiden sijaan yleisesti aikaamme ja opiskelijoiden ikään liittyviin tekijöihin, kuten sukupolveen, eläkeläisyyteen elämänvaiheena, ikääntyvään yhteiskuntaan ja teknologian kehitykseen.

Vaikka elinikäisen oppimisen ideologiaan, samoin kuin ylipäätään koulutukseen, sisältyy tasa-arvoistavia, väestöä integroivia tavoitteita, yhtä olennainen osa niiden toimintalogiikkaa on erottautuminen (Edwards ym. 2001, ks. myös Muhonen 2013). Samalla kun elinikäisen oppimisen politiikka ja ikääntyvien yliopistot lisäävät sosiaalista osallisuutta, luovat ne myös ulkopuolisuutta. Myöhemmän iän opiskelijat ikääntyvien yliopistossa havainnollistavat tätä koulutusinstituutioita yleisesti kuvaavaa kaksiteräistä miekkaa: elinikäisen oppimisen politiikassa marginaaliin jäävät eläkeikäiset nousevat ikääntyvien yliopistoissa koulutukselliseen keskiöön ja edustavat samanikäisten, ikääntyvän yliopiston ulkopuolelle jäävien näkökulmasta eläkeläisten eliittiä.

Elinikäisen oppimisen ideologiaan sisältyvää väitettä yhteiskunnan jatkuvasta muutostilasta on kritisoitu kyseenalaistamalla muutospaineiden itsestäänselvyys kaikenikäistä väestöä samalla tavoin koskettavana. Myöhemmän iän opiskelua kuvaa vapaaehtoisuus - opiskelijan ei tarvitse puntaroida enää opiskelusta saamiaan hyötyjä työuralla etenemisen kannalta. Tässä mielessä elinikäiseen oppimiseen liitetyt elinkautisuus ja pakot eivät kuvaa myöhemmän iän opiskelua. Vaikka työelämän ohittaneen opiskelijan oppimistarpeet ovat erilaiset kuin nuorempien, muutospaineet tunkeutuvat myös eläkeikäisten arkeen. Opiskelijat kirjoittavat teknologian kehityksen aiheuttamien muutosten työntyvän opiskelupakkona työelämän jälkeisiin päiviin. Muutospuhetta ei liitetä yhteiskunnan ja talouden hyötynäkökulmiin vaan sen avulla kuvataan henkilökohtaisia arjen tilanteita, jotka edellyttävät uuden oppimista. Uusien tietojen ja taitojen oppimisessa on kyse halusta toimia yhteiskunnan täysivaltaisena jäsenenä; opiskelijoiden 
sanoin myös pelosta pudota kelkasta tai konkreettisemmin mahdollisuudesta jakaa yhteisiä asioita lastenlasten kanssa. Osittain halu yhteiskunnan vauhdissa pysymiseen kääntyy pakoksi jatkuvaan oppimiseen.

Sen lisäksi, että artikkeli kuvaa, millaisin ehdoin myöhemmän iän opiskelua yhteiskunnassamme oikeutetaan, se havainnollistaa, miksi juuri ikääntyvien yliopistossa opiskelu koetaan houkuttelevaksi, verrattuna esimerkiksi opiskeluun muissa vapaan sivistystyön oppilaitoksissa tai varsinaisen yliopiston puolella. Yliopisto-opintojen houkuttelevuus kytkeytyy 1900-luvun alun Suomessa koulunsa käyneiden kokeneeseen koulutuksen puutteeseen (Kauppila 2002; Muhonen 2013). Toisaalta opinnot varsinaisen yliopiston puolella eivät houkuttele ikääntyvien yliopistolaisia, koska toiminnan koetaan rakentuvan nuorempien opiskelijoiden ehdoilla. Ikääntyvien yli- opisto muodostaa yhteisön, jossa opiskelijat kokevat yhteenkuuluvatta muiden samassa elämäntilanteessa olevien opiskelijatovereidensa kanssa. Suhteessa elinikäisen oppimisen keskusteluihin, joissa eläkeikäinen opiskelu kulkee marginaalissa, ikääntyvien yliopistot näyttäytyvät eräänlaisena kolmannen iän ja aktiivisen vanhenemisen symboleina, myöhemmän iän opiskelua kulttuurisesta toiseudesta nostavina instituutioina (vrt. Ojala 2010, 76).

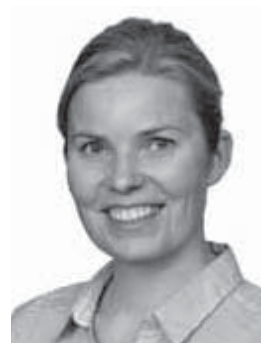

Reetta Muhonen

YTM, tutkija

Yhteiskunta-ja kulttuuritieteiden yksikkö

Tiedon, tieteen-, teknologian-ja innovaatiotutkimuksen yksikkö, TaSTI

Tampereen yliopisto

\section{LÄHTEET}

Alanen, A. \& Sihvonen, J. (toim.) (1981). Elinikäinen kasvatus. Helsinki: Gaudeamus.

Alasuutari, P. (1999). Laadullinen tutkimus. Tampere: Vastapaino. 3. painos.

Berger, P. L. \& Luckmann, T. (1994). Todellisuuden sosiaalinen rakentuminen: tiedonsosiologinen tutkielma. Alkuperäisteos Social construction of reality 1966. Suomentanut ja toimittanut Vesa Raiskila. Helsinki: Gaudeamus.

Creswell, J. W. (2007). Qualitative inquiry \& research design: choosing among five approaches. Thousand Oaks, CA: Sage. Second edition.

Delanty, Gerard (2003). Ideologies of the knowledge society and the cultural contradictions of higher education. Policy Futures in Education 1(1), 71-82.

Edwards, R., Armstrong, P. \& Miller, N. (2001). Include me out: critical readings of social exclusion, social inclusion and lifelong learning. International Journal of Lifelong Education 20 (5), 417-428.

Harva, U. \& Laurila, A. (1969). Elinikäinen kasvatus. Vapaan kansansivistystyön XVI vuosikirja. Helsinki: Otava.
Euroopan komissio (2000). Elinikäinen oppiminen. Komission yksiköiden valmisteluasiakirja. Euroopan yhteisöjen komissio, Bryssel. (Luettu 22.2.2013.) http://ec.europa.eu/education/lifelong-learningpolicy/doc/policy/memo_fi.pdf

Glendenning, F. (2000). Teaching and Learning in Later Life: Theoretical Implications. Studies in Educational Gerontology 4.

Jyrkämä, J. (2001). Odotuksia, tilaa ja unelmia? Keskustelua niin sanotusta kolmannesta iästä. Teoksessa Rantamaa P. (toim.) Lähellä ja kaukana: kirjoituksia työtovereilta Marjatalle ja Marjatasta. Jyväskylän yliopisto, yhteiskuntatieteiden ja filosofian laitos, 119-132.

Jyrkämä, J. (2013). Käsikirjoitus. Kolmas ikä, sukupuoli ja toimijuus. Teoksessa Ojala, H. \& Pietilä, I. (toim.) Miehistä puhetta. Miehet, ikääntyminen ja vanhenemisen kulttuuriset mallit.

Karisto, A. (2002). Kolmannen iän käsitteestä ja sen käytöstä. Gerontologia 16 (3), 138-142.

Karvonen, S. \& Rahkonen, O. (2002). Kuka vastustaa koulutusta? Yhteiskuntapolitiikka 67 (4), 324-332. 
Kauppila, J. (1996). Koulutus elämänkulun rakentajana. Teoksessa Antikainen, A. \& Huotelin, H. (toim.) Oppiminen ja elämänhistoria. Aikuiskasvatuksen 37. Vuosikirja. Helsinki: Kansanvalistusseura ja Aikuiskasvatuksen Tutkimusseura, 45-108.

Kauppila, J. (2002). Sukupolvet, koulutus ja oppiminen. Tulkintoja koulutuksen merkityksestä elämänkulun rakentajana. Akateeminen väitöskirja. Joensuun yliopiston kasvatustieteellisiä julkaisuja 78.

Kauppila, J. (2006). Elinikäinen oppiminen suomalaisessa oppimisyhteiskunnassa. Teoksessa Suoranta, J., Kauppila, J. \& Rekola, H. (toim.) Aikuiskoulutus risteysasemalla. Joensuun yliopiston täydennyskoulutuskeskus, 35-65.

Kilpeläinen, Arja (2000). Naiset paikkaansa etsimässä - Aikuiskoulutus naisten elämänkulun rakentajana. Akateeminen väitöskirja. Jyväskylän yliopisto.

Manninen, J. (2010). Elinikäinen oppiminen tappaa. Sivistys. (Luettu 27.2.2013.)

http://www.sivistys.net/nakokulmat/tieteen_sana/ elinikainen_oppiminen_tappaa.html

Moody, H. R. (1976). Philosophical presuppositions of education for old age. Educational Gerontology 1, 1-16.

Moore, E. (2003). Pitkä opintie. Aikuisiällä suoritettu tutkinto ja koulutuksellisen elämänkulun muutos. Yhteiskuntatieteellisiä julkaisuja 61, Joensuun yliopisto.

Muhonen, R. \& Ojala, H. (2004). Ajassa muuttuva kolmas ikä. Gerontologia 18 (1), 10-17.

Muhonen, R. \& Piesanen, E. (2006). Korkeakoulutus osana elämänlaajuista oppimista. Teoksessa Ursin, J. \& Välimaa, J. (toim.) Korkeakoulutus teoriassa. Näkökulmia ja keskustelua. Jyväskylän yliopisto, Koulutuksen tutkimuslaitos, 185-213.

Muhonen, R. (2011). Opiskelua Humboldtin hengessä ikääntyvien yliopistot yliopistollisuutta etsimässä. Teoksessa Ursin, J. \& Lasonen, J. (toim.) Koulutus yhteiskunnan muutoksissa: jatkuvuuksia ja katkoksia. Jyväskylä: FERA.

Muhonen, R. (2013). "Työläisten lapsista ei herroja kouluteta". Kokemuksia opinteillä etenemisestä itsenäisyyden alun Suomessa. Sosiologia 50 (1), 29-45.

Ojala, H. (2010). Opiskelemassa tavallaan. Vanhat naiset ikäihmisten yliopistossa. Akateeminen väitöskirja. Tampere University Press.

OPM (1997). Oppimisen ilo: kansallinen elinikäisen oppimisen strategia. Elinikäisen oppimisen komitea. Komiteanmietintö 1997/ 14. Opetusministeriö: Edita.

Patton, M. Q. (2002). Qualitative research \& evaluation methods. Thousand Oaks, CA: Sage. Third edition.

Raggat, P, Edwards, R, \& Small, N. (1996). Introduction: from adult education to a learning society? Teoksessa Raggat, P., Edwards, R. \& Small, N. (toim.) The learning society: challenges and trends. Lontoo ja Newyork: Routledge, 1-9.
Rossi, J. (2012). Sähköpostitiedustelut Jyväskylän ikääntyvien yliopiston opiskelijoiden keski-iästä ja opiskelijamääristä 3.2.2012 ja 30.10.2012.

Rubenson, K. (2006). The Nordic model of lifelong learning. Compare 36 (3), 327-341.

Sallila, P. (toim.) (2003). Elämänlaajuinen oppimien ja aikuiskasvatus. Aikuiskasvatuksen 44. vuosikirja. Helsinki: Kansanvalistusseura.

Sankari, A. (2004). Ikääntyviä tietoyhteiskunnassa. Kulttuuriset ajattelutavat ja sosiaalinen tila. Akateeminen väitöskirja. Jyväskylän yliopisto, SoPhi.

Siivonen, P. (2010). From a "student" to a lifelong "consumer" of education? Constructions of educability in adult students' narrative life histories. Akateeminen väitöskirja. Jyväskylä: FERA.

Silvennoinen, H. Tulkki, P. \& Honkonen, P. (1998). Jälkikirjoitus: Iloisesti oppien hyvään elämään. Teoksessa Silvennoinen, H. \& Tulkki, P. (toim.) Elinikäinen oppiminen. Helsinki: Gaudeamus, 215-251.

Silvennoinen, P. (2007). Ikä, identiteetti ja ohjaava koulutus. Ikääntyvät pitkäaikaistyöttömät oppimisyhteiskunnan haasteena. Akateeminen väitöskirja. Jyväskylä Studies in Education, Psychology and Social Research 303. Jyväskylän yliopisto.

Thomas, W.I. (1923). The Wishes. Teoksessa The unadjusted girl with cases and standpoint for behavior analysis. Boston: Little Brown and Company, 1-40. (Luettu 25.2.2013.)

http://www.brocku.ca/MeadProject/Thomas/ Thomas_1923/Thomas_1923_1.html

Tikka, M. (1990). Myöhemmän iän opiskelun tulkintamalleja. Gerontologia, 4 (2), 99-111.

Tuomisto, J. (1994a). Elinikäisen oppimisen muodot - teoreettiset lähtökohdat ja käytäntö. Teoksessa Kajanto, A. \& Tuomisto, J. (toim.) Elinikäinen oppiminen. Helsinki: Aikuiskasvatuksen Tutkimusseura ja Kansanvalistusseura, 13-45.

Tuomisto, J. (1994b). Elinikäinen kasvatus. Aatteesta strategiaksi. Teoksessa Kajanto, A. \& Tuomisto, J. (toim.) Elinikäinen oppiminen. Helsinki: Aikuiskasvatuksen Tutkimusseura ja Kansanvalistusseura, 49-84.

Tuomisto, J. (2002). Elinikäisen oppimisen retoriikka ja vallankäyttö. Teoksessa Honkonen, R. (toim.) Koulutuksen lumo - Retoriikka, politiikka ja arviointi. Tampere University Press, 15-34.

Tuomisto, J. (2003). Elinikäisen oppimisen toinen sukupolvi - unohtuiko jotain. Teoksessa Sallila, P. (toim.) Elämänlaajuinen oppiminen ja aikuiskasvatus. Aikuiskasvatuksen 44. vuosikirja. Helsinki: Kansanvalistusseura, 49-83. 